\title{
Es cosa suya: entanglements of border externalization and African transit migration in northern Costa Rica
}

\author{
Nanneke Winters ${ }^{1,2^{*}}$ (D) and Cynthia Mora Izaguirre ${ }^{3}$
}

\author{
* Correspondence: \\ nanneke.winters@uni-mainz.de \\ ${ }^{1}$ Department of Anthropology and \\ African Studies (ifeas), Johannes \\ Gutenberg University Mainz, Forum \\ universitatis 6, 55099 Mainz, \\ Germany \\ ${ }^{2}$ Institute of Development Policy \\ (IOB), University of Antwerp, Lange \\ Sint Annastraat 7, 2000 Antwerpen, \\ Belgium \\ Full list of author information is \\ available at the end of the article
}

\begin{abstract}
Starting from the idea that border externalization - understood as the spatial and institutional stretching of borders - is enmeshed with the highly contextual humanitarian and securitarian dynamics of migrant trajectories, this article addresses the reach of border externalization tentacles in Costa Rica. Although Costa Rica does not formally engage in border externalization agreements, it is located in a region characterized by transit migration and transnational securitization pressures. Moreover, externalization efforts across the Atlantic have contributed to a relatively new presence of so-called extra-continental migrants. Given these circumstances, we aim to interrogate the ways in which border externalization plays a role in Costa Rica's discourses, policies and practices of migration management. We do so by analysing a migrant reception centre in the northern Costa Rica border region, and by focusing on African transit migration. Our analysis is based on exploratory field research at the centre as well as on long-term migration research in Central America. Building on these empirical explorations and the theoretical notions of mobility regimes, transit and arterial borders, the article finds that Costa Rica's identity as a 'humanitarian transit country' - as enacted in the migrant reception centre - both reproduces and challenges border externalization. While moving towards increased securitization of migration and an internalization of its border, Costa Rica also distinguishes itself from neighbouring countries by emphasizing the care it extends to African migrants, in practice enabling these migrants to move further north. Based on these findings, the article argues for a deeper appreciation of the role of localregional histories, perceptions, rivalries, linkages and strategies of migration management. This allows for a better grip of the scope and shape of border externalization across a diversity of migration landscapes.
\end{abstract}

Keywords: Border externalization, Mobility regimes, Transit, Humanitarianism, Securitization, Migrant reception centres, African migrant trajectories, Costa Rica, Central America

\section{Introduction}

After a short tour of a state-run migrant reception centre in La Cruz, Costa Rica, during which the officer of Costa Rica's Immigration and Naturalization Service (in short, Immigration) responsible for the centre kept emphasizing the freedom of movement of the African migrants accommodated there, the question became almost inevitable: isn't there a tension between some of the main tasks of Immigration, controlling migration

(c) The Author(s). 2019 Open Access This article is distributed under the terms of the Creative Commons Attribution 4.0 International License (http://creativecommons.org/licenses/by/4.0/), which permits unrestricted use, distribution, and reproduction in any medium, provided you give appropriate credit to the original author(s) and the source, provide a link to the Creative Commons license, and indicate if changes were made. 
and combating smuggling, and the awareness that these migrants seek to continue their irregular journey north? The Immigration officer responded: "We provide them with care. If they want to continue [their journey north], es cosa suya [it's their business; it's up to them]." When asked whether the Immigration officer, who is from La Cruz himself, was aware of any smuggling dynamics - in this border town with a history of clandestine cross-border traffic in goods and people - he said: "We don't control what happens outside the centre. But Immigration is working on that." (Field notes from La Cruz, 22 August 2017)

This short excerpt from research on African migrant trajectories ${ }^{1}$ in Costa Rica illustrates a number of important clues for advancing the discussion on border externalization. These include the interlocking of humanitarian and securitarian mechanisms (Casas-Cortes et al., 2015, p. 74), the 'autonomous' quality of migration (Casas-Cortes, Cobarrubias, \& Pickles, 2015; Papadopoulos, Stephenson, \& Tsianos, 2008), and, in particular, the way in which both these issues take shape in, get shaped by, and in turn shape specific localities (Menjívar, 2014). As the 'spatial and institutional stretching' of borders and their locally specific mechanisms of care and control (Casas-Cortes, Cobarrubias, \& Pickles, 2015, p. 905), externalization takes place in a diversity of transit contexts. This article is about the reach of border externalization tentacles in Costa Rica, a country that is not traditionally targeted by externalization efforts, yet faced with a mobile population and located in a region that are both under extreme migratory scrutiny.

From early 2015 up until now, Costa Rica has been an important Central American hub of recently increased African transit migration across Latin America (Drotbohm \& Winters, 2018). This migration provides an exemplary case of the entanglements between ever-expanding border externalization and increasingly drawn-out and fluctuating migrant trajectories (Mainwaring \& Brigden, 2016; Schapendonk, 2011, 2017). African migrants who intend to reach North America, either directly from their home countries or from in-between destinations such as Brazil, face numerous impediments for legal travel and therefore undertake a largely irregular and highly complex journey by airplane, bus, boat and foot. The various migration opportunities, blockages and challenges they encounter along the way, including a highly contentious border between Costa Rica and Nicaragua, result in 'turbulent trajectories' (cf. Schapendonk, 2011) or 'fragmented journeys' (cf. Collyer, 2007; Mainwaring \& Brigden, 2016).

Such migrant trajectories do not traverse an empty transit space but incorporate various localities along migration routes (Mainwaring \& Brigden, 2016; Marcelino \& Farahi, 2011; Phillips \& Missbach, 2017; Vogt, 2013, 2016). These localities, with their own histories, complexities and sensitivities, and the migrant trajectories that cross them, interact with processes of border externalization that may be imposed from 'above' but nonetheless take their particular shape 'on the ground'. This interaction involves a multiplicity of state and non-state actors, discourses, encounters, practices, and infrastructures in different settings (Vogt, 2017, p. 194).

Taking into account these multiple, far-reaching and shifting spaces in which the border is practiced, in this article we ask to what extent recent developments in Costa Rica's migration management can be understood in terms of border externalization. Even though Costa Rica does not formally engage in border externalization agreements, it is located in a region in which both transit migration and transnational securitization pressures are substantial. Moreover, Costa Rica is being traversed by African migrants 
partly as a result of externalization efforts across the Atlantic that make migrating from Africa to Europe increasingly difficult (Marcelino \& Cerrutti, 2012). Given these circumstances and this relatively new group of migrants that Costa Rica is faced with, we aim to interrogate the ways in which border externalization plays a role in Costa Rica's discourses, policies and practices of migration management.

In order to address this question, the article analyses the migrant reception centre in $\mathrm{La}$ Cruz, a town close to Costa Rica's northern border with Nicaragua, where local humanitarian and securitarian dynamics surrounding African migrants 'in transit' materialize. It does so by exploring the following three aspects: first, the La Cruz border and migration landscape. Second, the establishment and functioning of its migrant reception centre. And third, the ways in which humanitarian and securitization policies get their particular shape in the centre, through the discourses and practices of state officials and their humanitarian affiliates. To be sure, although the article mainly focuses on the perspective of the Costa Rican state and its actors, it necessarily views this perspective in interplay with that of migrants and local residents alike.

Based on these empirical explorations and building on theoretical notions of mobility regimes (Papadopoulos et al., 2008), transit (Phillips \& Missbach, 2017) and arterial borders (Vogt, 2017), the article finds that Costa Rica's identity as a 'humanitarian transit country' - as enacted in the centre - both challenges and reproduces border externalization. On the one hand, Costa Rica juxtaposes its own, supposedly humane treatment of transit migrants with the neglect of these migrants elsewhere in the region. On the other hand, in its emphasis on being a transit country and its subsequent measures to regulate transit migrants, it also incorporates securitization discourses that effectively mirror regional externalization efforts. Moreover, by providing African migrants with documents that allow them to access the migrant reception centre and its services, Costa Rica eventually enables these migrants to continue their journey, thereby possibly complicating other countries' externalization efforts. Based on these findings, the article argues for a deeper appreciation of the role of local-regional histories, perceptions, rivalries, linkages and strategies of migration management. This allows for a better grip of the reach and shape of border externalization across a diversity of contexts.

In methodological terms, the paper builds on almost two decades of professional expertise with migration policy and practice in Costa Rica, which Cynthia Mora Izaguirre acquired through research, teaching and consultancy in university, government and NGO (Non-governmental organization) settings. It also builds on previous migration research in the broader Central American region by both researchers; and makes extensive use of secondary sources such as newspaper articles and blog posts. Furthermore, the article draws on two weeks of explorative fieldwork in Costa Rica's capital San José and northern border town La Cruz in August 2017, a study conducted by Nanneke Winters. This explorative study aimed to get a general sense of recent African migration in Costa Rica, as a first step in a larger research project on the trajectories of African migrants across Central America. ${ }^{2}$ In this article we zoom in on La Cruz, where the fieldwork focused on the migrant reception centre, the migrants accommodated there, and local residents. Interviewees included two representatives of Costa Rica's Immigration and Naturalization Service and the Red Cross, a police officer, a taxi driver, several members from Nanneke's local host family, and eight migrants. Five male migrants from Somalia, Eritrea, Nigeria and Haiti, and three female migrants from Haiti, 
Congo and Angola were interviewed in a mix of English, Spanish and French. ${ }^{3}$ All persons included in the study were approached through a purposive snowballing technique, and were included based on informal consent. After the study, both authors discussed the empirical material and its relevance for work on migration in the region in different academic settings. ${ }^{4}$

In what follows, we first go into the main theoretical building blocks that will help introduce the particular notion of border externalization that we work with. After an elaborate contextual description we will introduce the empirical material from La Cruz and its migrant reception centre, followed by a discussion of the ways in which we may understand Costa Rica's management of African transit migration in terms of externalization. In the conclusion we will pull these threads together, keeping in mind the continuing complexity of Costa Rica's migration landscape in the light of new groups of Latin American refugees that seek asylum in this country.

\section{Mobility regimes, transit and arterial borders}

Following Casas-Cortes, Cobarrubias, and Pickles (2015, p. 905), we understand border externalization as the 'spatial and institutional stretching' of borders. This means that the control of migrants does not only take place along the territorial limits of nation-states, but is directed at wherever migrants are (Casas-Cortes et al., 2015, p. 73). It is a type of migration management that involves bi- and multilateral cooperation and a host of policies, practices and technologies in order to discourage, deter and channel migrants, in other words, in order "to govern [migrants'] movement before, at and after the border" (Casas-Cortes et al., 2015).

Although border externalization (or: remote control, cf. Zaiotti, 2016) starts with nation-states' desire to regulate, contain and reduce (certain types of) migration, the process is rife with out-of-control dynamics that complicate neat, top-down interventions. Recent scholarship on migration or mobility regimes usefully indicates how efforts to externalize borders involve complex power relationships that make straightforward control by entity A over entity B implausible. According to Papadopoulos et al. (2008, p. 164), "the concept of the regime allows us to investigate the relation between the actions of migrants and those of agents of control without invoking a simplistic relation between subjects (cast as agents of control) and objects (understood as migrants or those who assist migrants) of migration." The notion of a regime also acknowledges the many different actors (as opposed to two neat 'entities') that are part of border externalization. In any given scenario of migration management different state, supra-state and non-state actors may be involved, who, in discourse and practice, are engaged in a continuous and open-ended struggle to categorize, il/legalize and embody human im/mobility (Glick Schiller \& Salazar, 2013).

The different actors and activities involved in mobility regimes are not only linked, but also sustain each other (Vogt, 2016). In particular, this can be seen in the 'care and control' entanglements between discourses of hospitality and crisis, practices of humanitarian aid, and nation-state policies (Casas-Cortes et al., 2015; Drotbohm, 2016; Fassin, 2005; Rozakou, 2012; Vrăbiescu \& Kalir, 2017). The search for those deserving humanitarian support requires intensive policing, and involves victimizing (a few) specific migrants according to specific policy categories as well as illegalizing (many more) others and their claims, often related to the demonization of smugglers (Ticktin, 2016; 
see also Crawley \& Skleparis, 2017; Sharma, 2003). The general criminalization of border crossing that involves such victimizing and illegalizing feeds into profit. For example, it justifies the employment of expensive security forces, centres and technologies (Vogt, 2016), instruments that have become a central aspect of border externalization.

As border externalization builds on the interconnections between care and control, it uses politicized arguments to enlist so-called transit countries in its project of remote migration control (Frelick, Kysel, \& Podkul, 2016, pp. 192-195). These arguments further extend securitization and humanitarian discourses to emphasize the transnational fight against crime and terrorism, as well as development assistance and capacity building for the transit countries that become (reluctant/unequal) partners in controlling migration. Migration scholars have increasingly critiqued the terminology of transit as an extremely politicized and simplistic denomination of migrants on the move and the zones where they pass through on their way to the next destination (Collyer, Düvell, \& de Haas, 2012; Marcelino \& Farahi, 2011; Phillips \& Missbach, 2017). At the same time, however, scholars acknowledge that the current interplay between an increased policy focus on 'suspicious' transit migrants and ever-evolving irregular migratory routes, 'uncontrollable' transit zones, and efforts of border externalization, merits further attention (see also Collyer, 2007; Hess, 2012). This acknowledgement fits scholarship that attempts to go beyond the binaries of origin and destination to make sense of in-between migration phases (Schapendonk, 2011, 2017). In this article, we accept the term transit for both the African migrants en route and for the Central American countries that they cross, while remaining critical of a too rigid, linear south-north logic that glosses over the detours, (temporary) emplacements and changes of heart that shape trajectories as well as transit zones (see Drotbohm \& Winters, 2018).

Certain countries that are labelled 'transit' are of course not merely empty space being transited but actively involved in producing, shaping, and steering migration. This not only means that in the current discourse of transit as a threat, they hold a bargaining chip in this otherwise extremely unequal playing field of migration management (Hess, 2012; for Mexico see also Dominguez \& Iñiguez Ramos, 2016), but also that border externalization from the 'North' inevitably amounts to internalization within the transit 'South'. ${ }^{5}$ According to Menjívar (2014), externalization is always coupled with internalization. The twin process of outsourcing and insourcing border control not only reinforces power imbalances between countries (sending, transit and receiving), but also within countries, in terms of the ways in which expanding borders transform zones and communities of transit through the extended temporary presence of migrants (or the semi-permanence of transit), new differentiations, and possibly violent confrontations that change the social fabric (Menjívar, 2014, pp. 359-360; Bredeloup, 2012; Marcelino \& Farahi, 2011; Phillips \& Missbach, 2017).

In order to increase understanding of the ways in which border externalization is enacted and experienced in specific localities in the so-called Global South, beyond the broad rubric of transit countries, Vogt's (2017) elaboration of Mexico's 'arterial border' provides useful inspiration. Vogt maintains that since the late 1980s, Mexico's interior has become characterized by sites of diffused migration enforcement strategies, taking the shape of what could be seen as an arterial border that "conceptualises power in terms of more fluid, multidirectional and contested 'regimes of mobility' along transit routes" (Vogt, 2017, p. 193). In Vogt's view, an arterial border involves ever-evolving 
bordering practices, the state and non-state actors engaged with these, their encounters, infrastructures and discourses, across an ever-expanding number of localities, in specific and historically shaped contexts (p. 194). The notion of an arterial border can thus capture the dynamism of local externalization/internalization entanglements in light of volatile migrant trajectories.

Building on these notions of mobility regimes, transit and arterial borders, in this article we interpret border externalization as the 'spatial and institutional stretching' of borders (Casas-Cortes, Cobarrubias, \& Pickles, 2015, p. 905) with an emphasis on the multiplicity of care and control actors, activities and power relationships involved, which are situated in specific localities that reach both outward and inward of nation-states. We now turn to the Central American context, which has rarely been included in border externalization literature (Kron, 2013) yet is heavily influenced by US border externalization via Mexico. Besides externalization targeted at Mexican migrants trying to cross the border into the United States, there has recently been an increase in efforts to further 'secure the south' of Mexico itself, against Central American and other migrants (Vogt, 2017, p. 196, see also Menjívar, 2014, p. 358). The development of collaborations and contestations related to border externalization between the United States and Mexico, and beyond, sets the stage for the complexity of migrant trajectories and Central American transit zones today.

\section{Border externalization in the Central American context}

\section{Securing the south: migrations, bargaining power and regional conflict}

Although it is not our intention to offer an exhaustive list of all border externalization agreements that have been established between the United States and Mexico or other Central American countries here, we will highlight a number of regional developments that are important for understanding the current situation in the northern Costa Rican border zone. ${ }^{6}$ Particularly since the 1990s, the United States has invested greatly in the securitization of its land and maritime borders to the south, often under the banner of a war on drugs and organized crime while simultaneously targeting migrants (Casillas, 2008; Galemba, 2013). It has attempted to secure its borders through direct force and through regional partnerships based on 'common' security concerns and free trade ideologies, diplomacy, and offers of funding, training, and equipment. Although it is debatable to what extent countries like Mexico have been receptive to pressure from the United States (Dominguez \& Iñiguez Ramos, 2016), it goes without saying that this decades-long border externalization has left its mark on the regional migration fabric.

This mark is not only visible in Mexico, the transit country which has received most attention, but also further south, where Mexico's struggle to secure its own border coincides with the United States' view to use Mexico as its buffer (Dominguez \& Iñiguez Ramos, 2016, p. 228). There has been a gradual shift of attention to Mexico's southern border in the past decade, in effect spilling over US-Mexico securitization efforts into the Central American countries of (mainly) Guatemala, Honduras and El Salvador. Successive border externalization interventions, with names such as 'Operation Hold-the-Line' and 'Smart Borders Initiative', ensure a gradual extension and melting together of the United States and Mexico's southern borders but do not constitute a straightforward process. Instead, it is infused with power hierarchies and conflicting 
interests, and consists of many different back-and-forth phases of migration, externalization and other geopolitical dynamics (as described in, amongst others, Dominguez \& Iñiguez Ramos, 2016; Fernández-Kelly \& Massey, 2007; Frelick et al., 2016; Frenzen, 2010; Menjívar, 2014; Podkul \& Kysel, 2015; Varela Huerta, 2015; Vogt, 2017; Zaiotti, 2016).

Based on the different phases discussed in the above-mentioned literatures, we have distinguished the following key themes that need to be taken into account for understanding current entanglements of border externalization in the region, including Costa Rica: a long history of migrations; the bargaining power of transit countries; and regional conflicts of interest. These themes are clearly intimately connected, as evidenced by the most recent Central American migrant caravan (see Winters, 2018). Regarding the first point of attention, it is important to remember that current dynamics of border externalization, and the ways in which these shape the transit of African migrants, build on earlier migrations and targeted attempts at border control. These range from United States interdiction at sea, aimed at intercepting irregular migrants from countries such as Haiti and Cuba in the 1980s, to the Southern Border Program addressing the 'unaccompanied minors crisis' of border-crossing Central American children and youth in 2014. These attempts at border control reflect the historical involvement of Mexico and Central America in irregular migration to the United States, both through the mobility of their own citizens and through the transit of other Latin Americans (Drotbohm \& Winters, 2018, p. 7), creating what Sandoval-Garcia (2015, p. 3) calls la triple frontera [the threefold border]: an unfolding push-and-pull system of transit, border-crossing and expulsion.

Although there is an extreme imbalance of power between the United States on the one hand and Mexico and Central American countries on the other, this does not mean that these transit countries are powerless pawns. The second point of attention in the region's border externalization concerns the specific type of leverage or bargaining power that these countries hold, perhaps as 'deficient partners' (Kron, 2013, p. 4), not only because the United States (and by extension Mexico) need these countries to control migration, but especially because a large portion of this migration originates in the very same countries that are targeted. In view of the ongoing violence, weak rule of law and socioeconomic exclusion that continue to displace people in the region (Cantor, 2014), Mexico and Central American countries can ask for coveted financial support as well as training, technology and equipment to address migration. Despite diverging interests, they can make use of specific discourses of security and human rights to somehow achieve a common agenda and receive such support. This happened, for example, in the Puebla Process (one of the first IOM-created Regional Consultative Processes on Migration (RCPs) from 1996 onwards), in which the central discourse of anti-trafficking brought together views from Canada to Panama (Kron, 2013, p. 3). Although the United States is clearly able to make firm demands for better border control, for example as a prerequisite to join in trade agreements, strategizing on a common agenda makes transit countries more than mere recipients of border externalization.

This brings us to the final point of attention, concerning the conflicting interests between these transit countries. Border externalization in Mexico, as well as corruption, impunity and general institutional weakness often result in violence against migrating Central American citizens (Aikin \& Anaya Muñoz, 2013; Alba, 2013; Brigden, 2017; 
Casillas, 2008; Martínez, 2014; Vogt, 2013, 2016). Other conflicting regional interests have become particularly clear in the event of Cuban and so-called extra-continental migration, the latter including African migrants. ${ }^{7}$ In 2015 the region witnessed a surge in Cuban migrants on their way north (via South America), driven by the fear that a favourable migration policy for Cubans who reach US soil would end given the change in diplomatic relations between the two countries. In November 2015, Nicaragua decided to formally block entrance for these Cuban migrants, resulting in what was widely termed a 'crisis' of stranded migrants in Costa Rica. According to the Nicaraguan government, this 'muro de contención' (wall of containment) was necessary to protect domestic security: the policy was framed in US-style security language referring to organized crime, especially trafficking in drugs and people. Other sources, however, point to animosity between Nicaragua and Costa Rica, the status of Cuba as an ally of Nicaragua, and the US being Nicaragua's primary trading partner, as playing a role in Nicaragua's decision (Silva, 2018). The exceptional solution by some Central American governments to move the Cuban migrants further north via an air bridge and bus transport across Costa Rica, El Salvador and Mexico, entailed further regional friction.

\section{African transit migrants in Costa Rica}

Nicaragua kept its border closed not only for Cubans, but also for a growing number of African migrants that started to arrive. The increase in African migrants who travel across Central America on their way to North America can be attributed to shifts in the worldwide migration landscape since the 1990s and especially the 2000s. These shifts are marked by ongoing displacement and the simultaneous development of disparate transatlantic migration regimes and industries, including Latin America's relatively porous borders, open migration policies, and limited state capacity to enforce these policies compared with Europe and North America (Drotbohm \& Winters, 2018, p. 6; see ACP Observatory on Migration, 2012; FLACSO, 2011; Marcelino \& Cerrutti, 2012; Mata Blanco, 2016; Savio, 2017; Vammen, 2017, p. 40). Notably, Latin American countries often lack deportation agreements with African countries.

Central America emerges as an important yet challenging corridor for those African migrants who intend to travel from South to North America (Mora Izaguirre, 2017; Nicolau, 2016; Rocha, 2016). As described by Drotbohm \& Winters (2018, p. 6), the route of these migrants commonly originates in West Africa (for example in Senegal, Ghana, Mali, Nigeria and Burkina Faso) and East Africa (Eritrea, Ethiopia and Somalia), as well as in the in-between migrant destinations of Portugal and Spain, and then continues via South America (Argentina, Brazil, Ecuador, Peru and Colombia). In Central America, the route mainly includes Panama, Costa Rica, Nicaragua (or its territorial waters), Honduras and Guatemala (see Lakhani, 2016; Mata Blanco, 2016; Nicolau, 2016). According to Rocha (2016), although this migration does not constitute a new phenomenon in the region, it has largely been invisible to the Central American public and invisibilized by Central American governments, including Nicaragua, which remains the only country that formally blocks these migrants.

The closure of the Nicaraguan border means that African migrants remain in Costa Rica while trying to find ways to cross irregularly (Winters, 2018). Of all the countries that lie on their route, Costa Rica stands out as a relatively stable, peaceful democracy. 
Famous for not having a military, it is generally considered an exceptional country given its lack of violence, civil war and dictatorship in the otherwise turbulent Central American region (Sandoval-Garcia, 2004), and it is widely recognized for its efforts to promote global human rights (Brysk, 2005). At regional level, notable examples of the latter include Costa Rica's key role in establishing and hosting the Inter-American Court of Human Rights (Brysk, 2005, p. 449) and in steering the Central American peace process in the 1980s (Brysk, 2005, p. 452), both of which contributed to its image as an 'island of peace' in Central America (Brysk, 2005, p. 460). Moreover, this image extends to Costa Rica's supposed hospitality towards migrants (Basok, 1990, p. 730; Fouratt, 2014), especially compared to other Central American countries. As a recent example, in Nicaragua citizens have been confronted with police violence for helping African migrants with food and other basics (Vílchez, 2016). In contrast, the treatment of extra-continental migrants by the Costa Rican state is usually considered relatively humane (Drotbohm \& Winters, 2018, p. 12; Fouratt, 2014).

This humanitarian image extends from formal state discourse and practice to Costa Ricans themselves, as reflected by newspaper and humanitarian reports as well as the accounts of the migrants during fieldwork. However, Costa Rica is not immune from securitization pressures, both foreign and domestic, which complicate hospitality. In the following sections, we will discuss the specifics of this humane/secure treatment for African transit migrants, in the context of Costa Rica's northern border dynamics, the locality of La Cruz, and its migrant reception centre.

\section{Costa Rica's northern bridging border}

\section{The La Cruz border locality}

According to Medina-Nicolas (2007, p. 101), "[t] he first qualifier that comes to mind for this border [between Costa Rica and Nicaragua] is 'alive'". It is a frontier characterized by dynamics that cross it, dynamics of conflict but mostly of exchange and integration (Kron, 2010; Medina-Nicolas, 2007; Rocha, 2007). Despite the fact that the Costa Rican and Nicaraguan state have a history of border disputes, the everyday lives of the local population on either side of the border are mostly characterized by cross-border interactions, relationships and interdependencies at both family and institutional levels (Medina-Nicolas, 2007, pp. 101-103). In addition, the lives of the border population are shaped by cross-border flows, both of short-distance, such as merchandise, cattle, and agricultural workers, as well as of longer-distance, such as migration.

La Cruz, in the north-western Costa Rican province of Guanacaste, is the main town in a canton of the same name, which hosts the Inter-American highway and Peñas Blancas, the only fixed migration checkpoint along the $300 \mathrm{~km}$ long border between Costa Rica and Nicaragua (Kron, 2010, p. 50). ${ }^{8}$ Next to this checkpoint, there are numerous 'blind spots' to cross this porous border (Kron, 2013, p. 4), facilitated by a well-established migration industry (Gammeltoft-Hansen \& Sørensen, 2013, pp. 6-7). With the involvement of local residents, entrepreneurs and authorities, formal and informal cross-border flows have shaped La Cruz as a border zone that binds more than it divides (Drotbohm \& Winters, 2018, p. 11). Multiple research participants referred to this bridging function of Costa Rica and of La Cruz in particular. If, as a local police 
officer suggested, "Costa Rica siempre ha sido puente [Costa Rica has always been a bridge]" (interview 22 August 2017), La Cruz is one of its main gateways.

In a small place like La Cruz, the smuggling dynamics that are part of Costa Rica's bridging function are relatively easily detectable. For instance, around the town's bus terminal, migrants can be seen meeting with smugglers (Drotbohm \& Winters, 2018, p. 11). The members of Nanneke's local host family also gave other examples. While shopping, they noticed an African or Haitian woman buying an 'exaggerated' amount of groceries at a local supermarket a few times in July 2016. Apparently, the woman went there with a man who was visibly uncomfortable during shopping and tried to hurry her. Their style of interaction and the quantity of groceries that they bought led the host family to conclude that they were a migrant and a coyote and that the woman was in charge of cooking for a larger group of migrants, perhaps secluded at a ranch nearby (interview 24 August 2017). A historically weak state presence in this border zone, coupled with the existence of 'zones of tolerance' despite a 'selective criminalization' of migrants and smugglers, and a certain level of complicity on behalf of border authorities (Kron, 2010), result in a grey zone in which a diversity of informal cross-border activities and mobilities are tolerated.

The complexity of this grey border zone has only increased in recent years, following Costa Rica's securitization concerns and strategies (Fouratt, 2014, 2016) as well as the presence of extra-continental migrants and the interventions to address these. This is not to say that these migrants are new to La Cruz. For example, small numbers of African migrants have been registered in Costa Rica and elsewhere in the region for at least a decade (Mora Izaguirre, 2017, p. 190). To illustrate, in her article on irregular migration and securitization discourses in Costa Rica, Kron (2010, p. 52) writes how she witnessed the detention of a small group of (presumably) Somali migrants at the Peñas Blancas migration checkpoint during fieldwork in 2010. Nanneke's host family in La Cruz has been living in the town for a decade and has also seen extra-continental migrants from time to time, for example, a small group of what they believe were Nepalese men in 2013. But these seem to have been more isolated cases, whereas currently this type of migration has become more common.

Moreover, in La Cruz, extra-continental migration gained prominence when an important smuggling route to cross Nicaragua was suddenly blocked. In November 2015, an intervention by the migration police interrupted a smuggling ring geared to migrants from Cuba, Asia and Africa (Castillo, 2015). According to the media and the host family, the leader of the smuggling network was a woman from La Cruz, whose estate bordered Nicaragua on the Pacific side of Peñas Blancas. She charged migrants to cross the border there unseen. When the migration police rounded up the smuggling ring that she was part of and the presence of law enforcement (momentarily) increased, this particular route closed, visibilizing hundreds of migrants who kept arriving via Panama but got stuck at this border (Drotbohm \& Winters, 2018, p. 11). As members of the host family said, "el flujo ya no fluyó [the flow no longer flowed]" (interview 24 August 2017). This event marked a new phase in Costa Rica's migration management in this particular zone.

The migrant reception centre: converging humanitarian and securitarian dynamics In 2016, Costa Rica's Immigration and Naturalization Service (DGME) established a migrant reception centre along the Inter-American highway just outside La Cruz, officially 
named the Centro de Atención Temporal para Migrantes (CATEM). The centre was established to temporarily yet orderly accommodate the migrants who got stuck at the Nicaraguan border, for whom informal facilities (which were installed during the 'crisis' with the Cuban migrants) no longer sufficed (interview with Red Cross representative, 22 August 2017). Of the thousands of extra-continental (and Haitian) migrants that were registered by Costa Rican Immigration that year, in August 2016 there were around 1000 persons accommodated in the centre in La Cruz (interview with Immigration officer, 24 August 2017). This number has since decreased. Although the centre has capacity for 2000 persons, to be divided over 40 donated US army tents, during fieldwork in August 2017 many tents were stored away because only about 70 persons were accommodated, including five families with around ten children, spread over 22 tents. Of this group, the male migrants came from Haiti, Eritrea, Ethiopia and Somalia, and the female migrants from Haiti, Congo, Cameroon and Gambia. At the time of writing this article, the centre also accommodated around 70 persons.

The services that this migrant reception centre offers include a secure accommodation with freedom of movement, food and space to cook, access to health care and translator services, and the translation of official documents into English and French (unpublished observations by Mora Izaguirre \& Miranda Jiménez, July 2018). ${ }^{9}$ Moreover, migrant families remain together. Children are followed up by a government organization that also provides some entertainment. In addition, children are allowed to go to school. However, this is uncommon given the difference in language and the assumed temporariness of their stay.

African migrants have access to the centre when they are in possession of a one-page form called the Permiso de Ingreso y Tránsito (PIT; permit of entry and transit). This is considered an exceptional status, which allows the Costa Rican state to impose a certain measure of control on this largely undocumented and largely un-deportable migration. It was established temporarily for the Cuban migrants in November-December 2015 in order to regularize and attend to that particular migration, but got extended to African migrants (as well as to other extra-continental migrants) in June 2016. Before extending the PIT to African migrants, in order to regularize their presence African migrants were required to appear for a 'firma periódica', a registration with migration authorities every 25 days. In addition, a limited number of others applied for refugee status. However, applying for refugee status has also been used as a way to regularize presence without the intention to stay. The PIT thus provides a more realistic status and measure of incoming African migrants (see Table 1). Although African migrants are not obliged to obtain a PIT, it gives them the right to circulate across the country

Table 1 Number of registered extra-continental migrants in Costa Rica

\begin{tabular}{|c|c|c|c|}
\hline \multirow[t]{2}{*}{2016} & \multicolumn{2}{|l|}{ Firma Periódica } & 1823 \\
\hline & \multicolumn{2}{|l|}{ PIT } & 18,301 \\
\hline 2017 & \multicolumn{2}{|l|}{ PIT } & 5975 \\
\hline \multirow[t]{3}{*}{2018} & \multirow[t]{3}{*}{ PIT } & January & 252 \\
\hline & & February & 474 \\
\hline & & March & 593 \\
\hline Total & & & 27,418 \\
\hline
\end{tabular}

Number of extra-continental migrants registered by Costa Rica's Immigration and Naturalization Service (DGME) between 2016 and March 2018, first via the Firma Periódica and afterwards via the Permiso de Ingreso y Tránsito (PIT; permit of entry and transit). Source: Costa Rica's Immigration and Naturalization Service (DGME), Costa Rica, May 2018 
and to access the migrant reception centre and its services at no cost. Furthermore, it is renewed automatically and indefinitely. In exchange for basic personal information and biometric data, a PIT provides immediate access to indispensable services for a migrant group that generally lacks a local support network.

The fact that the migrant reception centre offers an ordered, state-run space for humanitarian support not only provides the Costa Rican government with some control over these African migrants, but also with a means to assure its own citizens. Despite the humanitarian image of Costa Ricans, earlier experiences with different migrant and refugee groups show they are also familiar with prejudice and xenophobia (Basok, 1990, p. 730). Moreover, according to some of the research participants, the attention to thousands of Cuban migrants left La Cruz, a town of around 11,000 inhabitants, largely depleted of its social, commercial and institutional resources. "Con los cubanos se produjo un desgaste en el pueblo. ... Así que cuando llegaron los africanos, la gente decía: 'que les ayude el gobierno' [With the Cubans the town got worn-out. So when the Africans arrived, the people said: 'let the government help them']" (interview with host family members, 24 August 2017). Offering an enclosed, secure space where migrants could be attended to was actually the argument used by the staff of the centre to take away some of the local residents' 'worries' (preocupaciones) regarding the influx of African migrants (interview 22 August 2017). These worries, for example, related to possible diseases that migrants may carry, reflect certain prejudice. However, the research participants themselves attributed these worries to a lack of familiarity with darker-skinned persons and far-away cultures. As described by Drotbohm \& Winters (2018, p. 12), there is a small share of Afro-Mestizos in the Guanacaste province itself, and of Afro-Caribbeans in the Limón province to the southeast, but the presence of migrants with black skin was uncommon until recently (FLACSO, 2011, p. 6). Their 'exotic' image coupled with certain prejudice and a portrayal of these migrants as pobrecitos [unfortunate, poor souls] because of their long and difficult journey, makes them into clear candidates for experiencing the Costa Rican 'humanitarian disposition' (Drotbohm \& Winters, 2018, p. 12), exemplified through the attention they receive at the migrant reception centre.

This humanitarian disposition became evident in the ways in which the functioning of the centre was presented by the Immigration officer mentioned in the introductory vignette. During two interviews (22 and 24 August 2017), he recognized the plight of these migrants, and made sure to emphasize the flexibility of the centre in dealing with this 'exotic' group. For every past or potential problem that we discussed, there was a solution. For example, the Immigration officer demonstrated an area towards the back of the centre that was designated for cooking with elevated stoves (fogones). But according to the officer, when the staff of the centre realized that the migrants preferred to cook on the ground with fire wood (leña), they made space to do so because "es su cultura [it's their culture]". In addition, in terms of the food for cooking that is provided to the migrants, the staff of the centre took care not to offer pork but just fish and chicken, which "they all eat". The Red Cross representative offered another example when he stated that the Red Cross helps the migrants to clean the centre to show their goodwill, and that its staff has planted some crops to encourage a bit of independence and distraction (interview 22 August 2017). According to the Immigration officer, "hay que entender, se van por conflicto politico, por orientación 
sexual, por razones económicas... Lo más correcto para hacer es ayudarles [you have to understand, they leave because of political conflicts, sexual orientation, economic reasons... The right thing to do is to help them]" (interview 22 August 2017). His reasoning is in line with the predominant image of Costa Rica as a country that respects human rights.

But in the same centre, this humanitarian discourse is challenged on two levels. First, by some of the migrants accommodated there, and second, by the further securitization of migration. To start with the migrants, they have their own view of the support offered to them. Although they generally appreciate the hospitality of Costa Ricans and the safe space of rest and transit that the centre provides, they also debunked the centre's humanitarianism. For example, Islande, ${ }^{10}$ a Haitian woman in her 40 s, scoffed at the same measures that the Immigration officer praised (interview 24 August 2017). Before coming to Costa Rica, Islande had worked in the Dominican Republic for a year and in Brazil for 2 years. The economic and political turmoil in Brazil led her to join other migrants in their journey to the United States in 2016. She travelled for 3 months, partly as 'Congolese', before coming to Costa Rica and trying to cross its northern border. She paid 800 US dollars to cross into Nicaragua by boat and then continue by bus to Honduras. But once in Nicaragua, their group of migrants was robbed. After the robbing someone called the police on them and their group was deported back to Costa Rica. Islande has been in the centre ever since, and complained about the conditions there. For example, although the Immigration officer had said that the tents were not hot because they are partly made of gauze, Islande said they became very hot in Guanacaste's arid climate. Moreover, snakes and scorpions enter the tents. In addition, Islande does not like to cook on firewood. She cooks on gas. The differences in the accounts of the Immigration officer and Islande may be attributed to their disparate position and experience, in particular, given the dependent situation in which these migrants find themselves, the expectations they have of migrating and the frustration they may feel, stuck until new opportunities for continuing their journey north arise.

This points to the second challenge to the humanitarian discourse that the centre upholds, that is, the simultaneous securitization of migration. In order to be accommodated at the centre and eligible for support, migrants need to comply with certain requirements that allow Immigration - to a certain extent - to control them. They need to be able to show they are in the country legally (regular), by having been issued a PIT or, before this PIT status was established, by having been granted 25 days in the country (paso libre) upon registering with Immigration. In addition, in the centre there are various control measures in place, such as a daily attendance register and the obligation to wear blue bracelets. And although the Immigration officer maintained that "no les ponemos restricciones [we don't impose any restrictions on them]", migrants can officially only leave and enter the centre between $7 \mathrm{AM}$ and $10 \mathrm{PM}$ (interview 24 August 2017). ${ }^{11}$ The interplay between security, migration control and humanitarian support was further evidenced in the account of the Red Cross representative, who emphasized an explicit coordination between Immigration (order) and the Red Cross (care): "En realidad colaboran, se echan una mano cuando es necesario, no hay tensión entre sus objetivos [actually they collaborate, they help each other if necessary, there is no tension between their objectives]" (interview 22 August 2017). 
The migrant reception centre evidently serves both humanitarian and securitarian purposes, a dual logic of functioning that has been analysed for similar centres elsewhere (see, for example, Rozakou, 2012). The situation in La Cruz thus seems a classic example of 'care and control' dynamics of migration management. At the same time, however, the Immigration officer from the introductory vignette emphasized the agency of migrants and expressed a certain resignation on behalf of Immigration when he stated that if these migrants want to continue north, they can: es cosa suya. In order to understand this complexity, we need to unravel the ways in which the particular humanitarian discourses and practices of Costa Rica and its particular brand of securitization in La Cruz relate to border externalization.

\section{Es cosa suya: the local (mis) fit of border externalization}

As mentioned above, Costa Rica is not immune from border externalization pressures. Even though Costa Rica holds a somewhat peculiar position in the region, given its status as a migrant-receiving country and its relative independence from US funding and bargaining (compared to, for example, Mexico, Guatemala and Honduras), its position amidst various transit routes directed at the United States ensures its implication in border externalization. This implication is illustrated by Costa Rica's involvement in the Puebla Process or Regional Conference on Migration (RCM) from 1996 onwards. The RCM represents sustained multilateral coordination between Central and North America, and involves information sharing, capacity building of migration authorities, and the management of Central America's porous borders overall (Kron, 2013).

In addition, since 2005 Costa Rica has passed two new, restrictive immigration laws, which reflect the global trend towards securitization of migration as well as Costa Rica's domestic struggles over its (perceived) declining quality of life (Fouratt, 2016, p. 147). Making use in particular of the largest group of immigrants in the country, Nicaraguans, as scapegoats for social problems in Costa Rica, rhetoric in politics and the media has increasingly presented 'migration' as a crisis and a threat to Costa Rica's security and its national identity as a relatively peaceful and prosperous country (Fouratt, 2014, p. 147; Sandoval-Garcia, 2004; Voorend, 2014, p. 213). Although Costa Rica does not formally engage in border externalization agreements, the shift in discourse, policy and practice from migration 'hospitality' to 'security' (Fouratt, 2014, p. 145) reflects the logics of externalization efforts in the region (Kron, 2013).

As described by Noy and Voorend (2016), it is important to note here that this security shift does not stand on its own, rather, it interacts with other fields of policy and how these are executed. In the case of Costa Rica, the granting or denying of migrants' access to its relatively generous health care system has been used to manage migration (Noy \& Voorend, 2016). The latest immigration law of 2010 emphasized human rights and promoted the social inclusion of immigrants in response to civil society concerns. ${ }^{12}$ However, these rights are conditional upon a regular migratory status, which is increasingly difficult and costly to obtain (Fouratt, 2014). Noy and Voorend (2016, p. 619) argue that migrants find themselves in a 'catch-22 situation': in order to regularize their status, they need to be insured, whereas in order to be able to get insurance, they need to have a regular migratory status. This way, and in clear reflection of the interconnections between care and control, human rights are used to meet securitization demands. 
Moreover, making rights conditional fits into specific dynamics of border externalization, or to be more precise, into its twin of internalization (Menjívar, 2014). One of the implications of the 2010 immigration law was the internalization of Costa Rica's border well inside Costa Rica's territorial limits. According to Fouratt (2014), more authorities gained more power to establish 'comprehensive migration management' in the face of the 'security threat' that 'illegal' migrants pose. More specifically, by expanding migration information and management across a range of governmental and non-governmental institutions, the Costa Rican state solidified a security approach to migration throughout its territory (Fouratt, 2014, pp. 169-170), resembling Vogt's (2017) arterial border. The state not only made access to health care into an 'internal control measure' (Voorend, 2014, p. 202). The policing of migrants was also intensified through increased sanctions, detention and deportation (Fouratt, 2014, pp. 161, 167). Furthermore, in practice, the emphasis on human rights revolves mainly around anti-trafficking, which gets mixed with anti-drugs and anti-arms discourses, and materializes through an increased presence of police and control posts located on roads that lead to the border, on the look-out for migrants as well as potential smugglers / traffickers (Kron, 2013, p. 4).

Costa Rica thus partakes in practices of border externalization and internalization that resonate across the region. At the same time, however, the state also distinguishes itself from regional migration management by emphasizing its humane treatment of extra-continental migrants (unpublished observations by Mora Izaguirre \& Miranda Jiménez, July 2018). Other Central American countries do not provide similar attention to this migration - except for Panama, which has also established centres for registration and support. Moreover, according to a recent bi-national agreement Panama lets extra-continental migrants pass its northern border with Costa Rica in groups of maximum 100 persons, during three fixed days a week. Despite the existence of a number of fora on extra-continental migration, there is no such attention or cooperation in other Central American countries. Perhaps this is not surprising given the tension between assisting these migrants, which may be interpreted as endorsing irregular migration, and securitization. Furthermore, countries may use the lack of attention as a disincentive for staying, and may be weary of the high costs of such attention. By offering care to African migrants despite these conditions, Costa Rica can maintain its 'tradition' of respect for human rights, argue that it realistically tackles this migration, and remain committed to dignified and ordered migration, according to its minister of Communication (El País, 2016).

In practice, Costa Rica's attempt at the orderly, humane treatment of African migrants requires and results in their freedom of movement. The high turnover of migrants at the centre in La Cruz and the incidence of African migrants intercepted in Nicaragua or registered in Mexico testify to the possibilities of border-crossing as indicated by es cosa suya. Costa Rica's limited state capacity; its accommodation of the fact that most of these migrants want to move further north; its insistence on this fact for domestic stability; the tradition of smuggling entrepreneurship especially in La Cruz; and the agency of the migrants themselves ensure continued attempts at further mobility. During fieldwork, at least three groups of migrants left the centre. However, a large share of these migrants got returned quickly by the authorities, indicating the difficulty of crossing Nicaragua. 
Their freedom of movement is eventually only an extremely limited one. Still, the migrant reception centre and the regulatory function it performs do not seem designed to stop this migration; rather enabling migrants to rest and strategize before continuing their journey (see also Kron, 2010, pp. 52-53). Consequently, Costa Rica's ways of dealing with this transit migration, as a self-identified humanitarian transit country, may clash with externalization efforts further north.

\section{Conclusion}

In this article, we intended to disentangle and understand the ways in which border externalization plays a role in Costa Rica's discourses, policies and practices of migration management. The crucial and exceptional position of Costa Rica in this much-transited region provides an interesting case for looking into the stretching of borders, especially given the country's emphasis on human rights.

Through our focus on the complex connections between care and control, both within and beyond nation-state borders, and the specifics of the localities in which these connections take shape, we can see Costa Rica as a 'humanitarian transit country'. The ways in which this identity is enacted with African migrants in the migrant reception centre in $\mathrm{La}$ Cruz both reproduce and challenge border externalization. Costa Rica does not formally engage in regional agreements of border externalization, but its recent tendency in discourse, policy and practice towards securitization reflects such agreements. This securitization becomes especially clear in the increasing internalization of Costa Rica's border, in particular, through intensified policing of migrants and smugglers. Yet, when it comes to extra-continental migrants, Costa Rica is proud of its humanitarian tradition and emphasizes the attention it extends to these migrants compared to its neighbouring countries (with the exception of Panama). The ways in which this attention is put into practice, however, gives migrants the possibility to move further north. This could potentially provoke regional friction in the future, as differences in migration management have done before.

From the empirical material presented in this article, on a specific border locality situated in a region with a rich history of migrations, we see a clear need for further refinement of notions of border externalization. In particular, we argue for a deeper appreciation of the role of local-regional histories, perceptions, rivalries, linkages and strategies of migration management. These allow for a better grip of the reach and shape of border externalization across contexts. In this case, for example, they show how even a relatively independent state such as Costa Rica is not immune from the implications of externalization.

It would be interesting to see how Costa Rica's involvement with border externalization evolves in the future, especially given the (renewed) presence of Central American and other refugees. People who flee from violence and poverty in countries such as El Salvador and Honduras increasingly move south, to Costa Rica, instead of north. Given recent unrest in Venezuela and Nicaragua, new groups of refugees from these countries have also moved to Costa Rica. The differences between the reception and control of more established groups of migrants, these new groups and those that are deemed extra-continental, their interactions 
and intra-group differentiations, including the role of xenophobia and racism, and the different sites within Costa Rica where this reception, control, interaction and differentiation take place could provide valuable insight into current contexts of border externalization.

\section{Endnotes}

${ }^{1}$ For a reflection on the risk of essentialising 'migrants' in general and 'African migrants' in particular, see Winters \& Reiffen (in press).

${ }^{2}$ The explorative fieldwork was part of the project "African displacements and emplacements across Latin America", a research collaboration with Prof. Dr. Heike Drotbohm funded by the Johannes Gutenberg University Mainz (duration 2017-2018). Since October 2018, the subsequent research project of Drotbohm and Winters entitled 'African trajectories across Central America. Dynamics of displacements, transitory emplacements, and ambivalent migration nodes' receives funding from the German Research Foundation (DFG, duration 2018-2021).

${ }^{3}$ We decided to include the Haitian migrants that unintentionally became part of the fieldwork, because of their similarity in experience in terms of trajectories from Brazil and local reception in Cost Rica. In addition, many Haitian migrants have tried to pass as Congolese along the way to avoid deportation. See also Brigden (2016) for an analysis of Central Americans who try to pass as Mexicans on their way to the United States.

${ }^{4}$ Including in the panel "Experiencias actuales de migrantes y refugiados africanos en América Latina" at the 56th International Congress of Americanists (ICA Salamanca, July 2018).

${ }^{5}$ Although not the focus of this article, the simultaneous internalization of borders and the dynamics of transit are also of increasing concern for countries in the 'North'. For a critical reflection on the problematic distinction between 'North' and 'South', see Pinheiro (2013).

${ }^{6}$ For an overview or recent migratory policies to reinforce Mexico's southern border.

${ }^{7}$ The term 'extra-continental migration' is currently widely used throughout the region to label migrants from Africa, Asia and the Middle East. However, its political and material origins, connotations and effects require further scrutiny, a task which unfortunately lies beyond the scope of this article.

${ }^{8}$ There is another passageway by river, at the migration checkpoint of Los Chiles, located in the central-northern Alajuela province.

${ }^{9}$ Based on the paper 'Flujos mixtos en Costa Rica (2015-2017) dentro una dinámica estatal sin eco regional', presented by Cynthia Mora Izaguirre at the 56th International Congress of Americanists (ICA) in Salamanca, July 2018.

${ }^{10}$ Islande is a pseudonym.

${ }^{11}$ Circumvention of these formal regulations is of course still possible, as is evidenced by the groups of migrants who leave at night to continue their journey.

${ }^{12}$ For an extensive analysis of this process, see Fouratt (2014). 


\section{Acknowledgements}

We would like to thank the editors of this Special Issue and the anonymous reviewers for valuable feedback on earlier drafts of this paper. NW would also like to acknowledge the productive collaboration with Prof. Dr. Heike Drotbohm on the project "African displacements and emplacements across Latin America", the kind institutional support of the Department of Anthropology and African Studies (ifeas) in Mainz and the Institute of Development Policy (IOB) in Antwerp, as well as the pleasant cooperation with the African, Haitian and Costa Rican research participants. In particular, she would like to thank her host family in La Cruz. CMI would like to acknowledge the Oficina de Planificación Institucional and the Unidad de Comunicación Institucional, both part of Costa Rica's Dirección General de Migración y Extranjería (DGME; Immigration and Naturalization Service).

\section{Funding}

Internal University Research Funding from the Johannes Gutenberg University Mainz for preparing, conducting and interpreting the fieldwork in Costa Rica.

\section{Availability of data and materials}

The datasets generated and/or analysed during the current study are not publicly available due to privacy issues but are available from the corresponding author on reasonable request.

\section{Authors' contributions}

NW elaborated the theoretical framework, conducted the fieldwork, analysed the empirical data and wrote the main text. CMI contributed to the interpretation of the empirical data, elaborated crucial details on the context, and critically revised the text. Both authors have read and approved the final manuscript.

\section{Authors' information}

NW holds a PhD in Development Studies from the University of Antwerp, Belgium, for which she conducted ethnographic research on mobility and translocality among migrant families in Nicaragua, Costa Rica and Spain. She also conducted research with the Creole, Mestizo, and Central American migrant community in Belize. CMI holds a PhD in Political Sciences from the University of Rostock, Germany. Previously, she worked at Costa Rica's Immigration and Naturalization Service. Next to her research and teaching activities on migration and public policy, she is also a member of the Observatorio Latinoamericano de Trata, ObservaLAtrata: Capítulo Costa Rica.

\section{Competing interests}

The authors declare that they have no competing interests.

\section{Publisher's Note}

Springer Nature remains neutral with regard to jurisdictional claims in published maps and institutional affiliations.

\section{Author details}

${ }^{1}$ Department of Anthropology and African Studies (ifeas), Johannes Gutenberg University Mainz, Forum universitatis 6, 55099 Mainz, Germany. ${ }^{2}$ Institute of Development Policy (IOB), University of Antwerp, Lange Sint Annastraat 7, 2000 Antwerpen, Belgium. ${ }^{3}$ Instituto de Estudios Sociales en Población (IDESPO), Universidad Nacional de Costa Rica (UNA), Campus Omar Dengo, Apartado 86-3000, Heredia, Costa Rica.

Received: 7 September 2018 Accepted: 14 March 2019

Published online: 28 June 2019

\section{References}

ACP Observatory on Migration (2012). South-south extraregional migration: An overview of emerging trends (Background Note ACPOBS/2012/BN08). Retrieved from http://publications.iom.int/system/files/pdf/extraregional_migration_en.pdf.

Aikin, O., \& Anaya Muñoz, A. (2013). Crisis de derechos humanos de las personas migrantes en tránsito por México: Redes y presión transnacional [Human rights crisis of migrants in transit through Mexico: Networks and transnational pressure]. Foro Internacional, $211(\mathrm{LIII)}, 143-181$.

Alba, F. (2013). Mexico: The new migration narrative. Migration Information Source. Retrieved from https://www. migrationpolicy.org/article/mexico-new-migration-narrative.

Basok, T. (1990). Welcome some and reject others: Constraints and interests influencing Costa Rica policies on refugees International Migration Review, 24(4), 722-747.

Bredeloup, S. (2012). Sahara transit: Times, spaces, people. Population, Space and Place, 18, 457-467.

Brigden, N. K. (2016). Improvised transnationalism: Clandestine migration at the border of anthropology and international relations. International Studies Quarterly, 60(2), 343-354. https://doi.org/10.1093/isq/sqw010.

Brigden, N. K. (2017). Gender mobility: Survival plays and performing central American migration in passage. Mobilities. https://doi.org/10.1080/17450101.2017.1292056.

Brysk, A. (2005). Global good Samaritans? Human rights foreign policy in Costa Rica. Global Governance, 11, 445-466.

Cantor, D. J. (2014). The new wave: Forced displacement caused by organized crime in Central America and Mexico. Refugee Survey Quarterly, 33(3), 34-68.

Casas-Cortes, M., Cobarrubias, S., De Genova, N., Garelli, G., Grappi, G., Heller, C., ... Tazzioli, M. (2015). New keywords: Migration and borders. Cultural Studies, 29(1), 55-87.

Casas-Cortes, M., Cobarrubias, S., \& Pickles, J. (2015). Riding routes and itinerant Borders: Autonomy of migration and border externalization. Antipode, 47(4), 894-914. 
Casillas, R. (2008). Las rutas de los centroamericanos por México, un ejercicio de caracterización, actores principales y complejidades [The routes of Central Americans through Mexico, an exercise in characterization, principal actors and complexities]. Migración y Desarrollo, 10, 157-174.

Castillo, D. (2015, November 10). Policía desarticula banda internacional de tráfico de personas [Police disarticulates international human smuggling network]. La Nación. Retrieved from https://www.nacion.com/sucesos/crimenes/policiadesarticula-banda-internacional-de-trafico-de-personas/DQCWEC3NGBHNJIQHWZSTMHCXDQ/story/.

Collyer, M. (2007). In-between places: Trans-saharan transit migrants in Morocco and the fragmented journey to Europe. Antipode, 39(4), 668-690.

Collyer, M., Düvell, F., \& de Haas, H. (2012). Critical approaches to transit migration. Population, Space and Place, 18(4), 407-414.

Crawley, H., \& Skleparis, D. (2017). Refugees, migrants, neither, both: Categorical fetishism and the politics of bounding in Europe's 'migration crisis'. Journal of Ethnic and Migration Studies. https://doi.org/10.1080/1369183X.2017.1348224.

Dominguez, R., \& Iñiguez Ramos, M. (2016). The south/north axis of border management in Mexico. In R. Zaiotti (Ed.), Externalizing migration management. Europe, North America and the spread of 'remote control' practices, (pp. 225-237). London: Routledge.

Drotbohm, H. (2016, May 16). Porous walls: Fragmented protection in the face of migrants' displacement in Brazil [Blog post]. Retrieved from https://www.law.ox.ac.uk/research-subject-groups/centre-criminology/centreborder-criminologies/blog/ 2016/05/porous-wall.

Drotbohm, H., \& Winters, N. (2018). Transnational Lives en Route: African Trajectories of Displacement and Emplacement across Central America (Working Paper, No. 175). Department of Anthropology and African Studies of the Johannes Gutenberg University Mainz Retrieved from https://www.ifeas.uni-mainz.de/Dateien/AP_175.pdf.

El País (2016). Costa Rica destaca su defensa por DD.HH. en la atención de flujos migratorios [Costa Rica emphasizes its defense of human rights in attention to migratory flows]. Retrieved from https://www.elpais.cr/2016/12/18/costa-rica-destaca-sudefensa-por-dd-hh-en-la-atencion-de-flujos-migratorios/.

Fassin, D. (2005). Compassion and repression: The moral economy of immigration policies in France. Cultural Anthropology, 20(3), 362-387.

Fernández-Kelly, P., \& Massey, D. S. (2007). Borders for whom? The role of NAFTA in Mexico-U.S. migration. The Annals of the American Academy, 610, 98-118.

FLACSO (2011). Diagnóstico sobre la situación actual, tendencias y necesidades de protección y asistencia de las personas migrantes y refugiadas extracontinentales en México y América Central [Diagnostic of the current situation, tendencies and needs for protection and assistance of extra-continental migrants and refugees in Mexico and Central America]. Retrieved from http://www.corteidh.or.cr/sitios/Observaciones/11/Anexo8.pdf.

Fouratt, C. (2014). "Those who come to do harm": The framings of immigration problems in Costa Rican immigration law. International Migration Review, 48(1), 144-180.

Fouratt, C. (2016). Temporary measures: The production of illegality in Costa Rican immigration law. PoLAR: Political and Legal Anthropology Review, 39(1), 144-160.

Frelick, B., Kysel, I. M., \& Podkul, J. (2016). The impact of externalization of migration controls on the rights of asylum seekers and other migrants. Journal on Migration and Human Security, 4(4), 190-220.

Frenzen, N. (2010). US migrant interdiction practices in international and territorial waters. In B. Ryan, \& V. Mitsilegas (Eds.), Extraterritorial immigration control. Legal challenges, (pp. 375-396). Leiden: Martinus Nijhoff Publishers.

Galemba, R. B. (2013). Illegality and invisibility at margins and Borders. PoLAR: Political and Legal Anthropology Review, 36(2), $274-285$.

Gammeltoft-Hansen, T., \& Sørensen, N. (Eds.) (2013). The migration industry and the commercialization of international migration. London: Routledge.

Glick Schiller, N., \& Salazar, N. (2013). Regimes of mobility across the globe. Journal of Ethnic and Migration Studies, 39(2), 183-200.

Hess, S. (2012). De-naturalising transit migration. Theory and methods of an ethnographic regime analysis. Population, Space and Place, 18, 428-440.

Kron, S. (2010). "La frontera norte tiene tres problemas: tráfico de armas, de drogas y de migrantes." Migración irregular y discursos 'securitarios' en Centroamérica: el caso de Costa Rica ["The northern border has three problems: smuggling of weapons, drugs and migrants." Irregular migration and 'security' discourses in Central America: the case of Costa Rica]. Encuentro, 87, 38-60.

Kron, S. (2013). Central America: Regional migration and border policies. The Encyclopedia of Global Human Migration. https:// doi.org/10.1002/9781444351071.wbeghm110.

Lakhani, N. (2016, September 6). Passage through Mexico: The global migration to the US. The Guardian. Retrieved from https://www.theguardian.com/global-development/2016/sep/06/mexico-african-asian-migration-us-exit-permit.

Mainwaring, C., \& Brigden, N. K. (2016). Beyond the border: Clandestine migration journeys. Geopolitics, 21(2), $243-262$.

Marcelino, P. F., \& Cerrutti, M. (2012). Recent African immigration to South America: The cases of Argentina and Brasil in the regional context. In F. Reboiras, D. Leandro, \& J. Martínez Pizarro (Eds.), Development, institutional and policy aspects of international migration between Africa, Europe and Latin America and the Caribbean, pp. 107-145. Retrieved from https:// repositorio.cepal.org/handle/11362/3963.

Marcelino, P. F., \& Farahi, H. (2011). Transitional African spaces in comparative analysis: Inclusion, exclusion and informality in Morocco and Cape Verde. Third World Quarterly, 32(5), 883-904.

Martínez, Ó. (2014). The beast. Riding the rails and dodging Narcos on the Migrant Trail. London: Verso.

Mata Blanco, E. (2016, June 20). Hasta 20.000 africanos vienen hacia Costa Rica en su ruta a los Estados Unidos [Up to 20,000 Africans come towards Costa Rica on their way to the United States]. La Nación. Retrieved from https://www.nacion. com/el-pais/politica/hasta-20-000-africanos-vienen-hacia-costa-rica-en-su-ruta-a-los-estados-unidos/ NW4GNTDICZEGXNY3FBDM6ZFUW4/story/.

Medina-Nicolas, L. (2007). Central American borders at the core of the regional integration process. Geopolitics, 12(1), 78-108.

Menjívar, C. (2014). Immigration law beyond borders: Externalizing and internalizing border controls in an era of securitization. Annual Review of Law and Social Science, 10, 353-369.

Mora Izaguirre, C. (2017). De Brasil hasta Canadá: El paso de los extracontinentales por Costa Rica [From Brasil to Canada: The passage of extra-continentals through Costa Rica] In C. Mora Izaguirre (Ed.), Migraciones en Costa Rica. Un fenómeno 
histórico y dinámico desde diversas perspectivas disciplinares [Migrations in Costa Rica. A historical and dynamic phenomenon from diverse disciplinary perspectives], (pp. 175-203). San José: FLACSO.

Nicolau, L. (2016). Africans join the mass migration movement through Latin America. Humanosphere.

Noy, S., \& Voorend, K. (2016). Social rights and migrant realities: Migration policy reform and migrants' access to health care in Costa Rica, Argentina, and Chile. International Migration \& Integration, 17, 605-629.

Papadopoulos, D., Stephenson, N., \& Tsianos, V. (2008). Escape routes control and subversion in the twenty-first century. London: Pluto Press.

Phillips, M., \& Missbach, A. (2017). Transit Migration: Renewing the Focus on a Global Phenomenon, Introduction [Special issue]. International Journal of Migration and Border Studies, 3(2/3), 113-120. Retrieved from https://www.inderscience. com/info/inarticletoc.php?jcode=ijmbs\&year $=2017 \&$ vol=3\&issue $=2 / 3$.

Pinheiro, C. (2013). The Global South on Movement. Global South. SEPHIS magazine, 9(4), 10-15.

Podkul, J., \& Kysel, I. M. (2015). Interdiction, Border Externalization, and the Protection of the Human Rights of Migrants (Working paper). Retrieved from https://www.law.georgetown.edu/human-rights-institute/wp-content/uploads/sites/7/2017/07/ 2015-WRC-HRI-Submission-to-IACmHR.pdf.

Rocha, J. L. (2007, November). Ticaraguans: Bi-national Identities on the Liquid Border. Envío Digital (No. 316). Retrieved from http://www.envio.org.ni/articulo/3685.

Rocha, J. L. (2016, September). Miles de migrantes africanos en nuestras fronteras. (Thousands of african migrants at our borders.) Envio Digital, (No. 414). Retrieved from http://www.envio.org.ni/articulo/5245.

Rozakou, K. (2012). The biopolitics of hospitality in Greece: Humanitarianism and the management of refugees. American Ethnologist, 39(3), 562-577.

Sandoval-García, C. (2004). Threatening others. Nicaraguans and the formation of National Identities in Costa Rica. Athens: Ohio University, Center for International Studies.

Sandoval-García, C. (2015). NO MÁS MUROS. Exclusión y migración forzada en Centroamérica [No More Walls. Exclusion and Forced Migration in Central America] San José: Universidad de Costa Rica.

Savio, I. (2017, January 16). Los nuevos "espaldas mojadas": La ruta migratoria de los africanos hacia EEUU [The new 'wetbacks': the migratory route of Africans to the US]. El Confidencial. Retrieved from https://www.elconfidencial.com/ mundo/2017-01-16/africanos-ruta-migratoria-hacia-estados-unidos-latinoamerica-mexico_1316391/.

Schapendonk, J. (2011). Turbulent trajectories. Sub-Saharan African Migrants Heading North (Unpublished doctoral dissertation). Nijmegen: Radboud University Nijmegen. Retrieved from https://repository.ubn.ru.nl/handle/2066/91326.

Schapendonk, J. (2017). Navigating the migration industry: Migrants moving through an African-European web of facilitation/ control. Journal of Ethnic and Migration Studies. https://doi.org/10.1080/1369183X.2017.1315522.

Sharma, N. (2003). Travel agency: A critique of anti-trafficking campaigns. Refuge, 21(3), 53-65.

Silva, J. A. (2018, February 12). Migrantes atrapados en muro de contención de Nicaragua [Migrants trapped at Nicaraguan wall of containment]. Inter Press Service, Agencia de Noticias. Retrieved from http://www.ipsnoticias.net/2018/02/ migrantes-atrapados-muro-contencion-nicaragua/.

Ticktin, M. (2016). Thinking beyond humanitarian Borders. Social Research: An International Quarterly, 83(2), 255-271.

Vammen, I. M. (2017). Sticking to god: Brokers of Hope in Senegalese migration to Argentina. In N. Kleist, \& D. Thorsen (Eds.), Hope and uncertainty in contemporary African migration, (pp. 40-57). New York: Routledge.

Varela Huerta, A. (2015). La "securitización" de la gubernamentalidad migratoria mediante la "externalización" de las fronteras estadounidenses a Mesoamérica [The 'securitization' of migratory governmentability through the 'externalization' of US borders in Mesoamerica]. Con-temporánea. Toda la historia en el presente 4. Retrieved from https://mediateca.inah.gob. mx/repositorio/islandora/object/articulo:9944.

Vílchez, D. (2016, October 16). Antimotines reprimen a comunidad por auxiliar a migrantes [Anti-riot police represses community for helping migrants]. Confidencial. Retrieved from https://confidencial.com.ni/antimotines-reprimencomunidad-auxiliar-migrantes/.

Vogt, W. A. (2013). Crossing Mexico: Structural violence and the commodification of undocumented central American migrants. American Ethnologist, 40(4), 764-780.

Vogt, W. A. (2016). Stuck in the middle with you: The intimate labours of mobility and smuggling along Mexico's migrant route. Geopolitics, 21(2), 366-386.

Vogt, W. A. (2017). The arterial border: Negotiating economies of risk and violence in Mexico's security regime. International Journal of Migration and Border Studies, 3(2/3), 192-207.

Voorend, K. (2014). "Shifting in" state sovereignty: Social policy and migration control in Costa Rica. Transnational Social Review, 4(2-3), 207-225.

Vrăbiescu, I., \& Kalir, B. (2017). Care-full failure: How auxiliary assistance to poor Roma migrant women in Spain compounds marginalization. Social Identities. https://doi.org/10.1080/13504630.2017.1335833.

Winters, N. (2018, November 6) Redrawing the Central American Migrant Caravan: How Other (African) Trajectories Cross Its Path [Blog post]. Retrieved from https://www.law.ox.ac.uk/research-subject-groups/centre-criminology/centrebordercriminologies/blog/2018/11/redrawing-central.

Winters, N., \& Reiffen, F. (in press). Introducción. Experiencias actuales de movilidad, inmovilidad y haciendo-lugar de migrantes y refugiados africanos en América Latina [Número temático]. Introduction. Current experiences of mobility, inmobility and place-making of African migrants and refugees in Latin America [Special issue]. Revista Interdisciplinar da Mobilidade Humana (REMHU), 27(56).

Zaiotti, R. (2016). Mapping remote control. The externalization of migration management in the $21^{\text {st }}$ century. In R. Zaiotti (Ed.), Externalizing migration management. Europe, North America and the spread of 'remote control' practices, (pp. 3-30). London: Routledge. 